Methods A prospective, observational survey of language used in multi-disciplinary meetings over a two-week period across three hospices. Participants were blinded to data collection which was performed anonymously by one staff member on each site. The proportion of euphemisms were compared to 'd-words'.

Results Multidisciplinary teams were more likely to use the ' $\mathrm{d}$ words' (76\%; n: 241) than euphemisms (24\%; n: 75). There was variation between the hospices: $39 \%$ (n:50) compared with 17\% (n:20) and 7\% (n:5). This could be due to differences in staff or interpretation during data collection.

Conclusion Considering specialists in palliative care are heavily involved in discussions around death, it is unclear why $24 \%$ would opt to use euphemisms. Does this suggest fear within some professionals of talking about death openly? Are staff who use euphemisms amongst themselves more likely to use them with patients? Or by their use are staff exhibiting a sensitive approach to difficult issues? Further investigation is required to evaluate the use of euphemisms with patients and relatives and to compare across other healthcare settings.

\section{P-43 EMPOWERING PARENTS OF CHILDREN TO BECOME A THERAPEUTIC AGENT OF CHANGE}

Jolanta Martis. ellenor, Northfleet, UK

\subsection{6/spcare-2021-Hospice.63}

Background During lockdown parents who have children suffering with life- limiting illness or who experienced grief had considerably reduced access to professionals and face-to-face working. Hospices were challenged to adapt a new way of working. Momentous events that so fundamentally impact our entire society lead us to re-examine our belief structures and ways of working.

Aim To provide parents with the tools to enable them to feel more in control when everything else seems without control. To help create emotional openings, paths to their child's world.

Methods Parents were asked to attend a block of 10 online sessions to help them strengthen the relationship by using 30minutes structured playtime once a week, using a kit of carefully selected toys in their own home. Parents were provided with the guidance to help build the child's self-esteem, help the child learn self-control and responsibility. Providing dialogue, the parents were empowered to be a therapeutic agent of change for their child.

Results Written and verbal feedback indicated that parents felt more equipped to support and improve their parent/child relationship. The results support that the benefits of Child Parent Relationship Therapy (CPRT) may extend to the family system. They became more in control and prepared for the future on how to support their children. The parents valued flexibility in the approach.

Conclusions Our daily practices feel right and true to us, regardless of whether they have evolved to keep up with the pace of change. To initiate a new approach to current conditions, based on our experiences of COVID-19 and re-direction of support has been highly valued by patients and their families. However, they are not about making incremental changes that lead to new ways of doing things based on old beliefs. They are geared instead toward causing a total shift of perceptions, beliefs and thought process.
P-44 ABSTRACT WITHDRAWN

\section{P-45 THE LIFE AND DEATH PODCAST}

Helen Furnivall. Ashgate Hospicecare, Chesterfield, UK

\subsection{6/spcare-2021-Hospice.64}

Background During the pandemic, the humanity of death has often been lost. In October 2020, Ashgate Hospicecare launched The Life and Death Podcast to humanise the process of dying by telling universal stories through local voices.

Aims To open up conversations around death, hospice care and what 'dying well' really means.

Methods We brought together givers and receivers of end-oflife care to have honest conversations around the importance of a dignified death. In each episode, we met a different pair connected by Ashgate as they reflected on their unique relationships and the reality of end-of-life care. We worked closely with Reform Radio, a non-profit community production company, to record and edit the series which launched during Hospice Care Week.

Results 'This morning I watched the funeral of a dear friend being streamed. Tonight, I was sent this podcast and it has helped calm my scrambled thoughts.' This review, left during a national lockdown, demonstrates just how impactful this series has been. Another listener wrote, 'These are exactly the kinds of conversations we need to be having with each other, in order to become a society who can support each other through death and dying.' Unbelievably, the series reached the top 100 charts on Apple Podcasts, has received over 100 5* reviews and 3,800 listens. The podcast's release also attracted local press coverage, including The Derbyshire Times, Hasland Magazine, Destination Chesterfield, Imagine Radio and BBC Radio Sheffield. The podcast has been so successful that we have launched a second series, featuring Kathryn Mannix and other special guests.

Conclusions The Life and Death Podcast has opened up conversations that many find difficult, highlighted the importance of good quality end-of-life care and brought comfort to listeners across the country and beyond.

\section{P-46 BARRIERS TOWARDS PROVIDING EFFECTIVE SPIRITUAL CARE TO PALLIATIVE CARE PATIENTS}

Syed Qamar Abbas. St Clare Hospice, Harlow, UK

10.1136/spcare-2021-Hospice.65

Introduction Spiritual care is an integral part of palliative care. However, there is evidence that providing effective spiritual care is not achieved in most settings (O'Brien, Kinloch, Groves, et al., 2019; Harrad, Cosentino, Keasley, et al., 2019). Spiritual care means different themes for different people. These can be related to the need for meaning and purpose, to love and feel loved, the need to feel a sense of belonging and the need to feel hope, peace and gratitude. For some people, it can be related to their faith. There are still data to indicate that patients with some faiths are not served by hospices as per their population ratio (Public Health England, 2016; Ahmed \& Siddiqi, 2015; Currow, Ward, Plummer, et al., 2008). 